\title{
Reducing word stress errors: time restricted help for ESP students
}

\section{Ray Cooke}

\section{(2) OpenEdition}

\section{Journals}

\section{Electronic version}

URL: http://journals.openedition.org/asp/4283

DOI: $10.4000 / a s p .4283$

ISSN: 2108-6354

\section{Publisher}

Groupe d'étude et de recherche en anglais de spécialité

\section{Printed version}

Date of publication: 1 October 1993

Number of pages: 163-175

ISSN: 1246-8185

\section{Electronic reference}

Ray Cooke, «Reducing word stress errors: time restricted help for ESP students », ASp [Online],

2 | 1993, Online since 01 March 2014, connection on 02 May 2019. URL : http://

journals.openedition.org/asp/4283 ; DOI : 10.4000/asp.4283

This text was automatically generated on 2 May 2019.

Tous droits réservés 


\title{
Reducing word stress errors: time restricted help for ESP students
}

\author{
Ray Cooke
}

1 Few ESP students have the time or wish to learn the complex word-stress system in English. Many are obviously aware of the existence of stress, fewer of its communicative importance, and a sound working knowledge of it is the attribute of only a happy few. And no wonder! When word-stress is acquired on a haphazard, piecemeal basis, with little or no work having been done systematically before, the learner may find it largely aleatory and confusing, and both the aural and oral communicative performance of ESP students would improve if some effort were made to help them glean the basics. The image of the trembling young doctoral student delivering a speech to an international audience in which one word in five is unintelligible (and therefore most utterances) is by no means a myth.

2 Of course, times have changed. David Shillan (1954) had already identified the problem and proposed instructions for foreigners:

[...] with the help of which they may be enabled to speak so as to be understood by British people. Without such instructions [...] they may remain helpless, and unable indeed to understand much of what native English-speakers say. (preface)

But all he offers concretely is the information that more than one stress may be needed on the same word, and that

$[$ [...] in general, as the word grows longer, the stress tends to move along it.

4 This is not really a great deal of use. Four years later Roger Kingdon (1958) provided a much more complete analysis of word-stress, but the tendency is towards description of a system, with no real attempt at developing an accompanying pedagogy.

5 More recently, Jean-Louis Duchet (1991) provides an exhaustive analysis for students of English from degree-level onwards. The work is a 'tour de force', providing extremely pertinent insights for students of English at licence and concours level. But not really for ESP learners who need something pragmatic and time-saving to go on. The challenge therefore is to find some sort of short-cut, a method allowing learners to discover a system that they can really appropriate, one that will offer autonomous competence later 
on, a tool kit, but one which does not require many hours of patient study and observation. In brief, an exercise in damage limitation.

After all, what is important? Telling learners about Sacha Distel can be quite revealing and mark their conscience. Some years ago Sacha Distel had a prime-time TV show on BBC. Why Sacha Distel? Good singer, guitar player, perhaps intentionally speaking English with a French accent and charming because of it; a real Birkin reciprocal! But he got his stress right, otherwise he would not have got the job.

7 It is not until the seventies that one begins to see the publication of books in which learning strategies actually begin to be taken into account. Lionel Guierre (1970) is perhaps the first to appreciate fully the need for the learner's tool kit. His preface contains a "Summary of General Rules and Definitions" intended as a quick reference. What is immediately noticeable is a form of binary-style notation. The use of noughts, ones and twos to describe weak, secondary and primary stress respectively is a striking device, enabling the learner to reproduce mathematically what he may have some difficulty in hearing (and feeling). The system is excellent for students of English, but may be somewhat beyond the needs of ESP students. Take, for example, the section entitled "Bound Endings"; the last sentence could confuse the non-linguist.

Bound endings are weak in some contexts but can be elements of strong endings in others. For instance, '-al' is weak after '-ic' (logic, logical) and part of a strong ending ('gonal) in 'hexagonal' (compare hexagon). (1970: 13).

Nevertheless, Guierre's study, and those appearing in the eighties, provide the language learner with a very sound working knowledge of the stress system.

However, not all authors at the time feel there is a set of rules operating. John Wright (1973) is quite adamant about it:

English has no general rules for the placement of syllable stress [...]. This means that stress patterns must be learned from the dictionary ${ }^{1}$ (or teacher) when we learn the usage and meaning of a word. (1973: 16)

Imagine how the average ESP student's heart will sink if you tell them that! In the same vein, Valerie Adams (1973) has this to say:

Most writers on the sound-patterns of words use the term 'stress', but there is often confusion as to whether stress means 'loudness' or, more generally, 'prominence', from whatever cause, of a syllable. Since it is by now well established that change of pitch has more power to make a syllable stand out from its neighbours than increase of loudness, the term 'stress' seems best avoided. (1973: 35)

11 Little thought is being given here to simplifying for the learner what is in fact an interesting academic debate for the linguist. Nor is an apparent glossing over of learners' real needs a thing entirely of the past. Paul Tench (1981) would have it that...

Correct word accent can be practised by perceiving accented and unaccented syllables in words and phrases through ear-training exercises, and by imitation of correct pronunciation and also by developing an awareness of the variation of accent in derived forms of words (politics, political, politician) [...]. Many learners will not need anything more than straight imitation practise [...]. (1981: 72)

First, what are ear-training exercises, because we are not told. Then, who will give the correct pronunciation? Probably, the teacher, but there can be no guarantee that the model is given perfectly and that the learner perceives it correctly. Finally, developing an awareness of stress-shift is only one part of the story, and no device is suggested to help learners here, either. 

avoids using the term 'accent', since, among other things, it is used to refer to different varieties of pronunciation. He prefers the term 'stress' and the notion that

[...] difficult though the task is, one must try to find a way of writing rules that express what native speakers naturally tend to do in placing stress, (while acknowledging that there will always be a substantial residue of cases which appear to follow no regular rules). (Tutor's Book 1983: 36)

Roach's book which comes with a cassette is a highly useful and thorough account of the subject. It also offers the dual advantage of being usable for self-study in general, and in particular for work on specific points of difficulty as diagnosed by the teacher. For example, the section on word-class pairs like progress and progress gives an explanatory rule, then a full list of words. Indeed, each section contains its own rule, providing a total of well over a dozen rules.

The problem still remains, however, of hierarchising these rules. How can the ESP learner know which rules are more commonly applied, so that he may learn those and retain the others if possible?

Finally, mention should be made of Judy B. Gilbert (1984) and Clare Fletcher (1990). Both go a long way to meeting the need for a comprehensive and comprehensible self-study method. Gilbert sets up exercises for personal discovery, then gives clear rules in boxes. There are some simple but useful tips, too. For example, it is made explicit to the learner that strong stresses last longer than weak ones, and that...

[...] you need to concentrate only on the stressed vowels (Student's Book 1990: 21) an apparently simplistic assertion but one with much readily applicable meaning to the learner. Also, the graphic distinction made between clear and unclear vowels is very useful, plus the short note that $75 \%$ of two-syllable words are stressed on the first syllable, and that the figure is $90 \%$ if only nouns and adjectives are counted. The figures are open to discussion but do strike home as a rule-of-thumb.

Fletcher for her part has integrated communicative exercises into her study guide. Learners are encouraged to work together once a fairly comprehensive set of rules has been elucidated. Again the rules are boxed for clarity. In all this, then, what rules should the ESP student be learning, how much time should he or can he spend on it to become effective, and how can he learn it durably, for himself, without a teacher giving him pre-selected rules?

The following procedure which is valid for any specialty could be suggested. The learners are invited to select a 10-line passage from any fully scientific or popularized article. Then, they find in it a word corresponding to the stress pattern $\underline{\underline{00}}$ and call this the $\underline{\mathbf{0 o}}$ headword. I use this binary circles system I first saw used in a British Council workshop run by Brita Haycraft in the late seventies, but it may originate elsewhere. Then, $\underline{\mathbf{0 O}}, \underline{\mathbf{0 0 0}}$, $\underline{\mathbf{O o o}}$ and $\underline{\mathbf{o o O}}$ are done likewise, plus any words of four or more syllables. If the students

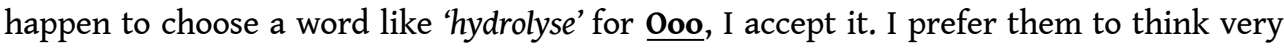
simplistically about this. According to Guierre's system, 'hydrolyse' would be 201, but I feel this to be too complex at this level of learning. Columns are then drawn and subgroups of three learners proceed to classify on a sheet of paper every word of two syllables or more in the text. If a group has a doubt, they ask me to say the word, which I do with my hand over my mouth and a volunteer's hand on my chest, in order to feel physically the strong stress. When the groups have finished they exchange papers and find any differences of 
opinion. Then information is pooled on the board and the correct classification of each word is checked together. If there is still doubt, I give the correct pattern if the learners prove unable to consult a dictionary that is always at hand during this session.

Figure 1

\begin{tabular}{|c|c|c|c|c|c|}
\hline Oo & 으 & oOOO & 000 & oo음 & OTHERS \\
\hline $\begin{array}{l}\text { poses } \\
\text { problems } \\
\text { solvents } \\
\text { further } \\
\text { powder } \\
\text { body } \\
\text { solid } \\
\text { liquid } \\
\text { offers } \\
\text { product } \\
\text { warmer } \\
\text { over }\end{array}$ & $\begin{array}{l}\text { despite } \\
\text { unique } \\
\text { demand } \\
\text { composed } \\
\text { include }\end{array}$ & $\begin{array}{l}\text { successful } \\
\text { container } \\
\text { important } \\
\text { consumer } \\
\text { acceptance } \\
\text { examples } \\
\text { dispensing } \\
\text { suspension } \\
\text { propellant } \\
\text { tremendous }\end{array}$ & $\begin{array}{l}\text { aerosol } \\
\text { excellent } \\
\text { usually } \\
\text { several } \\
\text { totally }\end{array}$ & & $\begin{array}{l}\text { formulation } \\
\text { especially } \\
\text { antiperspirants } \\
\text { insoluble } \\
\text { conventional } \\
\text { advantages } \\
\text { relatively } \\
\text { application } \\
\text { efficacy }\end{array}$ \\
\hline
\end{tabular}

21 The students are then asked to make any extrapolations they can from the board, which always looks something like Figure 1. 'Always' because this is so. Figures 2-4 represent three more taken from other specialties. ${ }^{2}$ The resemblance is striking, particularly regarding the number of entries in the first column. Now we teachers know that this will happen, but for the students this discovery, made when a member of the group announces it, is very rewarding, all the more so in that there is some element of healthy competition between learners to state the as yet unknown. So rule $n^{\circ} 2$ is appropriated by the group, rule $\mathrm{n}^{\circ} 1$ being that every word of two syllables or more has a strong stress. (This would previously have been established in the build-up to the session).

Figure 2

\begin{tabular}{|c|c|c|c|c|c|}
\hline Oo & 00 & 000 & 000 & 000 & OTHERS \\
\hline $\begin{array}{l}\text { abstract } \\
\text { lactate } \\
\text { resting } \\
\text { under } \\
\text { glucose } \\
\text { substrate } \\
\text { vivo } \\
\text { measure } \\
\text { membrane } \\
\text { compound } \\
\text { levels } \\
\text { uptake } \\
\text { measured } \\
\text { plasma }\end{array}$ & $\begin{array}{l}\text { effect } \\
\text { across }\end{array}$ & $\begin{array}{l}\text { uncoupler } \\
\text { conditions } \\
\text { aerobic } \\
\text { compart } \\
\text { ments }\end{array}$ & $\begin{array}{l}\text { different } \\
\text { cellular } \\
\text { medium } \\
\text { gradients }\end{array}$ & & $\begin{array}{l}\text { protonophoric } \\
\text { investigated } \\
\text { incubated } \\
\text { aerobiosis } \\
\text { anaerobiosis } \\
\text { energetic } \\
\text { vacuolar } \\
\text { phosphorylated } \\
\text { respiratory } \\
\text { independently } \\
\text { aerobically }\end{array}$ \\
\hline
\end{tabular}


Figure 3

\begin{tabular}{|c|c|c|c|c|c|}
\hline Oo & $\infty$ & oOo & 000 & 000 & OTHERS \\
\hline $\begin{array}{l}\text { patients } \\
\text { sixty } \\
\text { usual } \\
\text { studied } \\
\text { patterns } \\
\text { system } \\
\text { increase } \\
\text { septum } \\
\text { methods } \\
\text { using } \\
\text { any }\end{array}$ & $\begin{array}{l}\text { between } \\
\text { response } \\
\text { decline } \\
\text { until } \\
\text { along } \\
\text { results }\end{array}$ & $\begin{array}{l}\text { potentlals } \\
\text { recorded } \\
\text { conducting } \\
\text { specific } \\
\text { progressive } \\
\text { increasing } \\
\text { resulted } \\
\text { dramatic } \\
\text { duration } \\
\text { preceding } \\
\text { consistent } \\
\text { tricusoid }\end{array}$ & $\begin{array}{l}\text { amplitude } \\
\text { occupied } \\
\text { atrial } \\
\text { vertical } \\
\text { annulus }\end{array}$ & & $\begin{array}{l}\text { anterograde } \\
\text { continuum } \\
\text { electrograms } \\
\text { ventricular } \\
\text { corresponding } \\
\text { separating } \\
\text { disappearance } \\
\text { activity } \\
\text { posterior }\end{array}$ \\
\hline
\end{tabular}

Figure 4

\begin{tabular}{|c|c|c|c|c|c|}
\hline OO & 00 & 000 & Ooo & 000 & OTHERS \\
\hline $\begin{array}{l}\text { market } \\
\text { standards } \\
\text { level } \\
\text { certain } \\
\text { owing } \\
\text { Europe }\end{array}$ & $\begin{array}{l}\text { requires } \\
\text { amount } \\
\text { research } \\
\text { throughout } \\
\text { support }\end{array}$ & $\begin{array}{l}\text { creation } \\
\text { providing }\end{array}$ & $\begin{array}{l}\text { principal } \\
\text { unified } \\
\text { specialized } \\
\text { several } \\
\text { technical }\end{array}$ & & $\begin{array}{l}\text { community } \\
\text { development } \\
\text { industrial } \\
\text { European } \\
\text { neutrality } \\
\text { objectivity } \\
\text { activities } \\
\text { standardization }\end{array}$ \\
\hline
\end{tabular}

Figure 4bis: Totals (4 excerpts)

\begin{tabular}{|c|c|c|c|c|c|}
\hline Oo & OO & OO० & O00 & OOO & OTHERS \\
\hline 44 & 18 & 28 & 19 & & 37 \\
\hline
\end{tabular}

The following outlining ${ }^{3}$ may now be done (Fig. 5). The group again tries to extrapolate from this. If nothing happens, the word cricket mis-stressed and then correctly stressed usually jogs somebody into saying that the stressed syllable is more important because it gives more information. Here then is rule $n^{\circ} 3$.

Figure 5

\begin{tabular}{|c|c|c|c|c|c|}
\hline 00 & 00 & 000 & 000 & 000 & OTHERS \\
\hline $\begin{array}{l}\text { POSes } \\
\text { PROBlems } \\
\text { SOLVents } \\
\text { FURther } \\
\text { POWDer } \\
\text { BODy } \\
\text { solid } \\
\text { LIQUid } \\
\text { offers } \\
\text { product } \\
\text { WARMer }\end{array}$ & $\begin{array}{l}\text { despite } \\
\text { unique } \\
\text { demand } \\
\text { composed } \\
\text { include }\end{array}$ & $\begin{array}{l}\text { successful } \\
\text { container } \\
\text { important } \\
\text { consumer } \\
\text { acceptance } \\
\text { examples } \\
\text { dispensing } \\
\text { suspension } \\
\text { propellant } \\
\text { tremendous }\end{array}$ & $\begin{array}{l}\text { aerosol } \\
\text { excellent } \\
\text { usually } \\
\text { several } \\
\text { totally }\end{array}$ & & $\begin{array}{l}\text { formulation } \\
\text { especially } \\
\text { antiperspirants } \\
\text { insoluble } \\
\text { conventional } \\
\text { advantages } \\
\text { relatively } \\
\text { application } \\
\text { efficacy }\end{array}$ \\
\hline
\end{tabular}

Further outlining (Fig. 6) then provides rule $n^{\circ} 4$ which is that prefixes and suffixes seem to be weakly stressed. 


\begin{tabular}{|c|c|c|c|c|c|}
\hline$\underline{00}$ & 00 & 000 & 000 & 000 & OTHERS \\
\hline \begin{tabular}{|l} 
posES \\
problems \\
SolvENTS \\
furthER \\
powder \\
body \\
solid \\
llquID \\
offers \\
product
\end{tabular} & $\begin{array}{l}\text { despite } \\
\text { unique } \\
\text { Demand } \\
\text { COMposed } \\
\text { INclude }\end{array}$ & $\begin{array}{l}\text { SUccessFUL } \\
\text { CONtainER } \\
\text { IMportANT } \\
\text { consumER } \\
\text { ACceptance } \\
\text { examples } \\
\text { dispensING } \\
\text { SUSpenSION } \\
\text { propeliANT } \\
\text { tremendOUS }\end{array}$ & $\begin{array}{l}\text { aeroso } \\
\text { I } \\
\text { excellENT } \\
\text { usuaiLy } \\
\text { several } \\
\text { totalLY }\end{array}$ & & $\begin{array}{l}\text { formulaTION } \\
\text { especialLY } \\
\text { ANTIperspirANTS } \\
\text { insoluBLE } \\
\text { conventionAL } \\
\text { advantagES } \\
\text { relativeLY } \\
\text { APplicaTION } \\
\text { efficacy }\end{array}$ \\
\hline
\end{tabular}

New outlining (Fig. 7) gives rule $n^{\circ} 5$, that what could crudely be called the 'particularity' of a word is stressed strongly, but it may be necessary to add a few extra words such as fireman, landlady, doctor and sculptor so that extrapolation can take place.

Rule ${ }^{\circ} 6$ may also require the addition of a word or two, for example, the noun derived from an adjective or verb, or vice-versa, such as 'photo', 'photographer' and 'photographic'. It then becomes clear that stress can migrate. But for what reason? One or two further additions reveal why. If 'geographer' and 'geographic' are added here, then outlining shows there to be what could be called very simply a 'classic/typical word ending'. In fact, it may be unnecessary to add such words since there may already be appropriate occurrences, as is the case with Europe and European in Fig. 4. Duchet calls a group of these "Terminaisons Savantes" (e.g. -itis, -otis, -osis, -oma), but the term "classic/typical word ending' is all-encompassing. The text under study will reveal some of these, to which the teacher may contribute others, but any specialty has its terminology which must contain these.

The list is now complete, but rule $\mathrm{n}^{\circ} 7$ is far from being finished since a sublist must now be composed. The learners could be encouraged to break out of the verticalness of their own subject and think horizontally to find similar words from other areas. Sociologists therefore find that diagnostic imagery is used by radiologists. And that any -ographer uses his -ographic skills to practise -ography. Completion of this list is an ongoing task over time, but the session finishes with thorough consultation of the way word-stress is indicated in dictionaries.

whole session normally lasts about two hours, and the learners leave with what they are encouraged to consider as being a particular tool from an overall tool kit which it is their responsibility to acquire, and ours to help them to do so.

of course, such summary treatment of what is a complex area can in no way provide an explanation for every word. But that is not what ESP learners need or want, despite the genuine curiosity some may have as to exceptions to the rules. Indeed, any learner would do well to carry a small notebook in which peculiarities of classic Francophone errors of the 'area' or 'development' type are noted, or even words like engineer and understand which fit the unusual ooO pattern.

Admittedly there is a danger in such simplification for the learner. Using these rules-ofthumb may mean that a young doctor is led to say 'incidence' and 'prevalence' since he identifies prefixes which should be weakly stressed. The likelihood, though, is otherwise since intuition also intervenes to some extent. 
e the word-stress tool kit is in place, a whole range of subsequent activities then becomes more meaningful. Reading aloud with exaggerated stressing, breathing and speaking exercises, listening to native-speaker subject specialists for stressed features, video role play with subsequent self-criticism: all tending to give the learner confidence in his own ability to go some way to mastering this difficult parameter in English. With at the end, scrutiny by a third-party English native speaker to see if the latter really understands the learner's utterances.

It may be that a reasonable aim for ESP students is in the relatively short time available to acquire the tools of an oral performance combining intelligibility with Gallic charm; something akin to what Louis Alexander, in his assessment of the implications of the Waystage and Threshold levels, described as follows:

Defective but effective communication. ${ }^{4}$

\section{BIBLIOGRAPHY}

Adams, Valerie. 1973. An Introduction to Modern English Word-Formation. London: Longman.

Duchet, Jean-Louis. 1991. Code de l'anglais oral. Gap: Ophrys.

Fletcher, Clare. 1990. Longman Pronunciation Dictionary: Study Guide. London: Longman.

Gilbert, Judy B. 1984. Clear Speech. Cambridge: Cambridge University Press.

Guierre, Lionel. 1970. Drills in English Stress Patterns. London: Longman.

Haycraft, Brita. 1971. The Teaching of Pronunciation: A Classroom Guide. London: Longman.

Jabbour-Lagocki, J. 1992. "Medical terminology: A phonological analysis for teaching English pronunciation". English for Specific Purposes 11, 71-79.

Kingdon, Roger. 1958. The Groundwork of English Stress. London: Longman.

Mahandru,V.K. 1975. “The problem of word-stress in English"”. ELT Journal 29/2.

Roach, Peter. 1983. English Phonetics and Phonology: A Practical Course. Cambridge: Cambridge University Press.

Shillan, David. 1954. Spoken English. London: Longman.

Tench, Paul. 1981. Pronunciation Skills. London: Macmillan.

Wright, John. 1973. Speaking English. Oxford: Oxford University Press.

\section{APPENDIXES}

\section{Appendix: Excerpts corresponding to figures}

1. Despite the fact that it poses unique formulation problems, successful dispersion of suspended solvents from an aerosol container has come to be especially important in the 
tremendous growth of sales and consumer acceptance of antiperspirants. Further examples of powder dispensing aerosols with high consumer demand are body powders, foot sprays and pet powders. The suspension type spray composed of an insoluble solid and a liquid, usually a propellant, offers the consumer several advantages over the more conventional totally liquid aerosol product. These advantages can include warmer spray, relatively dry application and excellent product efficacy.

2. ABSTRACT: The effect of a protonophoric uncoupler (CCCP) on the different cellular compartments was investigated in yeast grown aerobically on lactate. These cells were incubated in a resting cell medium under three conditions in aerobiosis with lactate or glucose or in anaerobiosis with glucose as energetic substrate. For each condition, in vivo 31P NMR was used to measure $\mathrm{pH}$ gradients across vacuolar and plasma membrane and phosphorylated compound levels. Respiratory rate (aerobic conditions) and TPP+ uptake were measured independently.

3. Methods and Results: Sixty-four patients (mean age, $48+19$ years) with the usual form of AVNRT were studied. Slow low-amplitude potentials were recorded when using the anterograde AV conducting system. Slow potentials occupied all (giving a continuum of electrograms) or some of the time between the atrial and ventricular electrograms. Their most specific patterns were their progressive response to increasing atrial rates, which resulted in a dramatic decline in amplitude and slope, a corresponding increase in duration, and a separation from preceding atrial potentials until the disappearance of any consistent activity. Slow potentials were recorded along a vertical band at the mid or posterior part of the septum near the tricuspid annulus.

4. One of the Community's principal aims is the creation of a unified market, and this requires the development of industrial norms and standards at European level. This in turn calls for a certain amount of specialized research which, owing to the need for neutrality and objectivity, is a Community task 'par excellence'. Several groups of Community research activities are aimed at providing technical support for standardization throughout Europe.

\section{Some rules of thumb for stressing words}

As a French student of English, it is vital to have a sound working knowledge of the English stress system, for reasons we have already discovered together. Here are the real 'basics'. Your job from now on will be to observe the language, and try to expand the list in $n^{\circ} 7$.

1. Every word of 2 syllables or more has a strong stress.

2. Most words of two syllables are 'Oo'.

3. Strong stress on most important/informative part of word.

4. Prefixes and suffixes are normally 'weak'.

5. The 'particularity' of a word is 'strong', e.g. Landlady, Fireman =Oo(o)

6. Stress can migrate, e.g. 'Photo', 'Photographer', 'Photographic'.

7. There are some classic word endings: e.g.,

-ission, -ition, -icion, - ution $=-\mathrm{Oo}$

-ology, -ography, -onomy = -Ooo

-ologic(al), -ographic, - onomic $=-\mathrm{oOo}$ 


\section{NOTES}

1. Wright's underlining.

2. See Appendix: "Excerpts corresponding to figures".

3. This is the simplest technique on a white board. In this paper, however, enlarged characters are used in the Figures.

4. L. Alexander, "Some methodological implications of Waystage and Threshold levels", In Waystage English, Pergamon, Oxford (1977: 100).

\section{ABSTRACTS}

Few ESP students have the time or wish to embark on learning the complex word stress system in English. Yet their communicative performance would improve if they were aware of some rules of thumb. The report briefly reviews the literature, then describes a time-restricted approach for providing essential help in an area often perceived by students as being largely aleatory and unfathomable.

Le domaine de l'accentuation des mots en anglais est difficile à maîtriser dans le cadre de l'apprentissage d'un anglais de spécialité. En revanche, si quelques règles de base étaient acquises, la performance orale serait meilleure. L'auteur examine brièvement la littérature sur le sujet pour ensuite suggérer une courte démarche visant à faire découvrir l'essentiel dans ce domaine.

\section{INDEX}

Keywords: ESP, pragmatic help, word stress rule

Mots-clés: accentuation de mots, anglais de spécialité, règle de prononciation

\section{AUTHOR}

\section{RAY COOKE}

DLVP, Univ. Bordeaux 2. ray.cooke@lv.u-bordeaux2.fr 